University of Nebraska - Lincoln

DigitalCommons@University of Nebraska - Lincoln

2008

\title{
A revision of Australian Thrasorinae (Hymenoptera: Figitidae) with a description of a new genus and six new species
}

Matthew L. Buffington

Smithsonian Institution, matt.buffington@ars.usda.gov

Follow this and additional works at: https://digitalcommons.unl.edu/systentomologyusda

Part of the Entomology Commons

Buffington, Matthew L., "A revision of Australian Thrasorinae (Hymenoptera: Figitidae) with a description of a new genus and six new species" (2008). USDA Systematic Entomology Laboratory. 63.

https://digitalcommons.unl.edu/systentomologyusda/63

This Article is brought to you for free and open access by the Entomology Collections, Miscellaneous at DigitalCommons@University of Nebraska - Lincoln. It has been accepted for inclusion in USDA Systematic Entomology Laboratory by an authorized administrator of DigitalCommons@University of Nebraska - Lincoln. 


\title{
A revision of Australian Thrasorinae (Hymenoptera: Figitidae) with a description of a new genus and six new species
}

\author{
Matthew L Buffington* \\ Systematic Entomology Laboratory, USDA, c/o NMNH, Smithsonian Institution, 10th \& Constitution Ave NW. PO Box \\ 37012 MRC-168, Washington DC 20013, USA.
}

\begin{abstract}
A new genus of Thrasorinae (Hymenoptera: Figitidae) is described from Australia, and includes specimens reared from an unidentified Ophelimus species (Eulophidae: Ophelimini) on Eucalyptus cinerea (Myrtaceae). Mikeius, new genus, includes six species: M. berryi sp. n., M. gatesi sp. n., M. grandawi sp. n., M. hartigi (Girault) n. comb., M. neumanni sp. n. and M. schauffi sp. n.; M. hartigi is designated as the type species of Mikeius. Thrasorus Weld is revised, and the description of T. schmidtae sp. n. is provided, as well as a redescription of T. pilosus Weld. All records to date indicate that species of Mikeius and Thrasorus are associated with hosts that induce galls on species of Acacia and Eucalyptus, although most of these host records await verification. A list of world species of Thrasorinae is provided.
\end{abstract}

Key words Cynipoidea, Mikeius, new genus, new species, redescription, Thrasorus.

\section{INTRODUCTION}

Cynipoid wasps represent one of the more extensive radiations of extant parasitic Hymenoptera, with current estimates at just over 3000 described species (Ronquist 1999; Fontal-Cazalla et al. 2002; Buffington et al. 2007), but Nordlander (1984) estimated that 24000 species are likely to occur. Although cynipoids are recovered deeply nested within the entomophagous parasitic Hymenoptera (Ronquist et al. 1999; Dowton \& Austin 2001; Castro \& Dowton 2006), the majority of Cynipidae are obligate phytophages (Weld 1952; Ronquist 1999). Ronquist (1995, 1999) and Buffington et al. (2007) both point to two stem groups of cynipoids, i.e. Parnipinae and Thrasorinae, as examples of species whose biology lies somewhere between entomophagy and phytophagy. Hence, understanding the taxonomy, biology and phylogenetics of these groups helps elucidate the evolutionary origins of the phytophagous cynipid lineage.

The focus of this paper is a revision of the Australian Thrasorinae, including a description of a new genus, Mikeius gen. n. as well as a new combination, M. hartigi (Girault) and descriptions of five new species: $M$. berryi sp. n., M. gatesi sp. n., M. grandawi n. sp., M. neumanni sp. n. and M. schauffi sp. n. Also provided is a redescription Thrasorus pilosus Weld, including a description of the male for the first time, as well as the description of T. schmidtae sp. n. Included is a diagnosis of Thrasorus and Mikeius to allow separation from Nearctic and Neotropical thrasorine genera (and close relative), namely Euceroptres Ashmead, Myrtopsen Rübsaamen, Pegascynips

*matt.buffington@ars.usda.gov
Brèthes and the newly described Scutimica Ros-Farré (RosFarré \& Pujade-Villar 2007). A key to species of Thrasorinae of Australia is provided.

\section{MATERIALS AND METHODS}

Rearing methods. Branches with fully developed galls (Fig. 1F) were collected by I.-K. Kim (ANIC: Australian National Insect Collection, Canberra, Australia) from $E$. cinerea on the Commonwealth Scientific and Industrial Research Organisation (CSIRO) Black Mountain site in Canberra. To avoid mixing with other parasitoids of other insects on the host tree, all leaves were removed and then bare branches were placed in vinyl bags to collect wasps every 1 or 2 days.

Descriptions. Morphological terminology follows that of Ronquist and Nordlander (1989) and Fontal-Cazalla et al. (2002); cuticular surface terminology follows that of Harris (1979). Under each 'material examined' section, text within brackets is that of the author of this paper. Specimens were examined using a Leica Wild M10 with fluorescent lighting. Images for figures were obtained using an EntoVision Imaging Suite, which included a firewire JVC KY-75 3CCD digital camera mounted to a Leica M16 zoom lens via a Leica Z-step microscope stand. This system fed image data to a desktop computer where Cartograph 5.6.0 (Microvision Instruments, France) was used to capture a fixed number of focal planes (based on magnification); the resulting focal planes were merged into a single, in-focus composite image. Lighting was achieved using techniques summarised in Buffington et al. (2005). All images contained within this study are freely available from http://www.morphbank.com. In some cases, digital

Journal compilation (C 2008 Australian Entomological Society

No claim to original US government works 

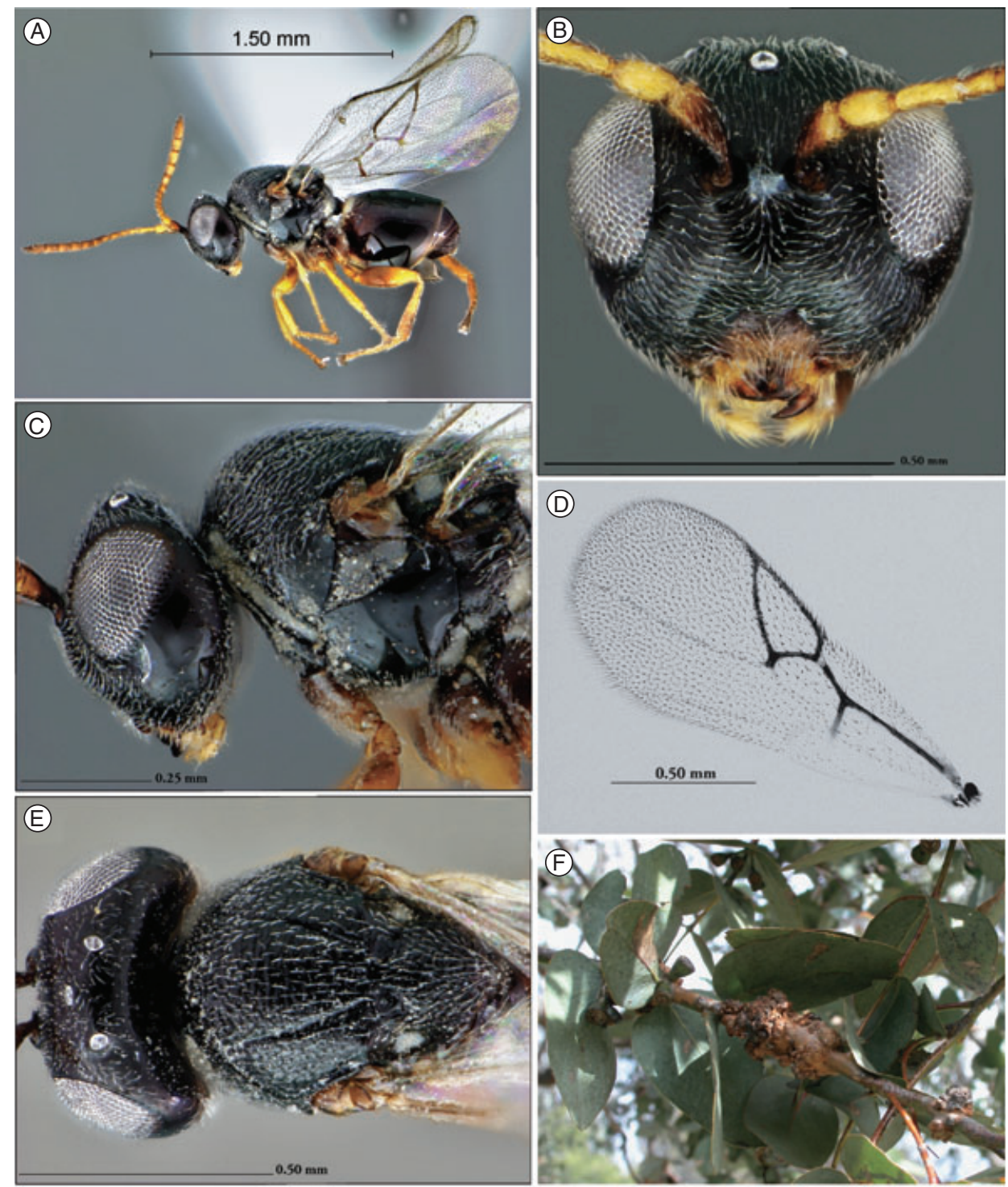

Fig. 1. Mikeius

hartigi

(Girault), female. (A) Habitus; (B) head, anterior view; (C) head and mesosoma, lateral view; (D) forewing; (E) head and mesosoma, dorsal view; (F) stem gall induced on Eucalyptus cinerea by an undetermined Ophelimus sp. (Eulophidae). Photo by I.-K. Kim. drawings were made from these composite images using Adobe Photoshop ${ }^{\odot}$. Collections of images stored on MorphBank can be accessed through the links provided in the text and collection numbers in Table 1.

\section{SYSTEMATICS}

\section{Key to species of Australian Thrasorinae}

1 A. Microsculpture of mesoscutum composed of pits widely separated by smooth and shiny cuticle (e.g. Figs 2C,3G-H)...................... Thrasorus, 2 B. Microsculpture of mesoscutum composed of dense horizontal striations; no part of mesoscutum smooth and shiny (e.g. Fig. 1E,3A-F)..... Mikeius new genus impression extremely short, represented by notch in posterior margin of mesoscutum (Fig. 3G).

T. pilosus Weld

B. Anterior margin of mesopleuron glabrous; mesoscutal impression absent (Fig. $3 \mathrm{H})$.

T. schmidtae sp. n.

3 A. Mesopleural carina absent, at most represented by few very faint striae (e.g. Fig. 1C)................ 4 B. Mesopleural carina present, represented by either one distinct carina or several well-developed and continuous striae...................................... 5

4 A. Scutellar fovea subtriangular; bottom of scutellar fovea with distinct rib-like sculpturing (Fig. 3B); mesopleuron with very weak striae only occasionally present............................... gatesi sp. n. C. Scutellar fovea round; bottom of scutellar fovea entirely smooth (Fig. 3C); mesopleuron without striae, entirely smooth.................... hartigi (Girault)

5 A. Anterior margin of mesopleuron with setiferous pits ........................................... 6 D. Anterior margin of mesopleuron with deep striae M. neumanni sp. n. 


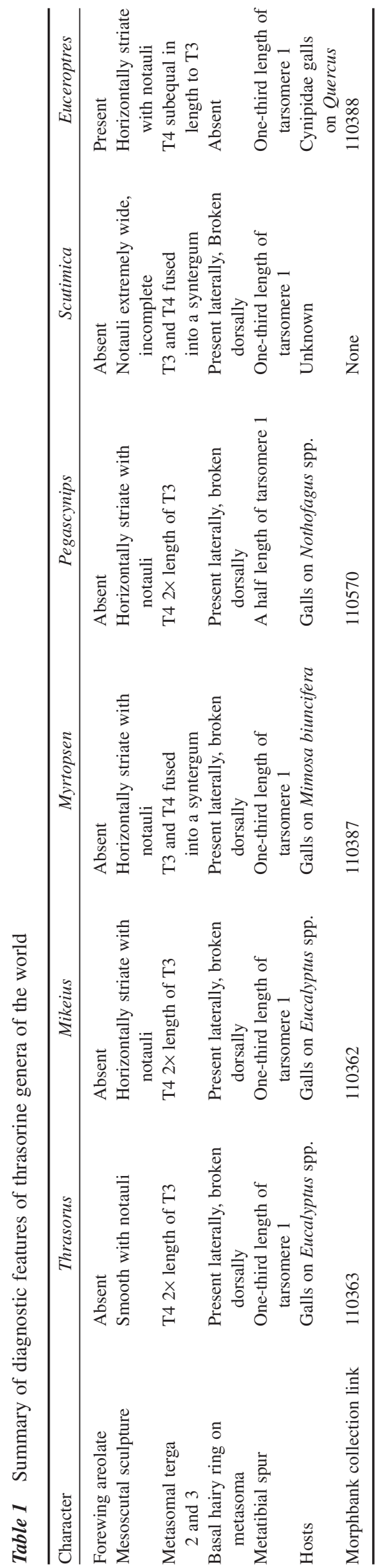

A. Mesoscutal impression one-third to a half length of mesoscutum (when measured from posterior margin of mesoscutum) (e.g. Fig. 3A,F)....................... 7 E. Mesoscutal impression present as notch on the posterior margin of mesoscutum (Fig. 3E) M. grandawi sp. n.

A. Lateral aspect of pronotum with distinct ridges.... M. schauffi sp. $\mathrm{n}$. F. Lateral aspect of pronotum without ridges, at most with setiferous pits separated by smooth cuticle.

M. berryi sp. $\mathrm{n}$.

\section{Diagnosis of Thrasorinae genera}

Ros-Farré and Pujade-Villar (2007) summarise the diagnostics of Thrasorinae, Plectocynipinae and Euceroptres. Members of the Thrasorinae tend to be morphologically homogenous. Table 1 summarises key diagnostic morphological and lifehistory features of each genus of Thrasorinae. Some characters of particular importance include forewing areolate present in Euceroptres Ashmead (absent in other thrasorines) and hairy ring absent at base of metasoma (other thrasorines have a dorsally interrupted hairy ring); terga 3 and 4 form a syntergum in Myrtopsen Rübsaamen and Scutimica Ros-Farré (terga 3 and 4 remaining distinct sclerites in other thrasorines); Scutimica has deep, incomplete notauli on the mesoscutum that forms an elongate pit; whereas, Myrtopsen has a transversely strigate mesoscutum and complete, narrow notauli, metatibial spur half the length of metatarsomere 1 in Pegascynips Brèthes (at most one-third length of metatarsomere 1 in other thrasorines); Thrasorus Weld has a smooth, shiny, mesoscutum with narrow, complete notauli (Figs 2C,3G,H); Mikeius gen. n. has a distinctly crenulate to horizontally strigate mesoscutum (Figs 1E,3A-F). A complete list of species of Thrasorinae is provided in Table 2.

\section{Mikeius gen. nov. (Figs I,3A-F)}

\section{Type species Amblynotus hartigi Girault, new combination}

Description (female). Head. Black; frons smooth to horizontally strigate; malar space variously strigate; gena and vertex smooth, shiny; entire head except gena covered in short appressed setae (Fig. 1A-E). Antennae orange, semiclavate, scape $1.25 \times$ length of radicle, short appressed setae on all flagellomeres, 12 flagellomeres present, moniliform; last two flagellomeres nearly fused (Fig. 1A).

Mesosoma. Lateral surface of pronotum polished to umbilicate, densely covered in short appressed setae (Fig. 1C). Mesopleuron polished, anterior end smooth to umbilicate; mesopleural carina present to variously strigate to absent; mesopleural triangle deeply impressed, setose, clearly defined along all edges (Fig. 1C). Mesoscutum transversely striate and moderately setose; anteroadmedian signum present; median mesoscutal impression present or absent, when present, onetenth to one-fourth length of mesocutum; notauli complete, 

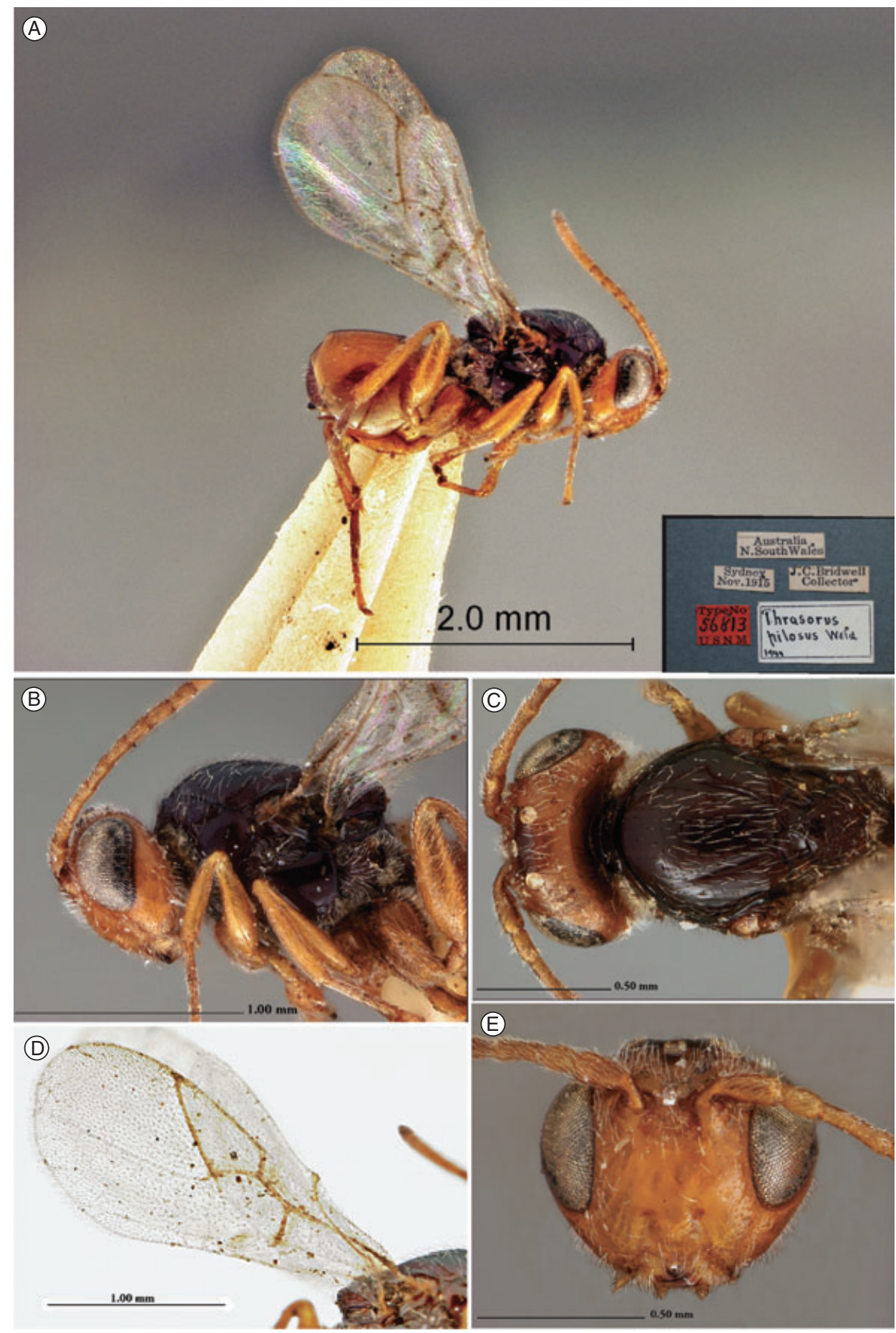

Fig. 2. Thrasorus pilosus, holotype, female. (A) Habitus; inset, specimen labels; (B) head and mesosoma, lateral view; $(\mathrm{C})$ head and mesosoma dorsal view; (D) right forewing; (E) head, anterior view.

originating at anterior end of parascutal impression; notauli of uniform width to slightly wider posteriorly (Figs 1E,3A-F). Disk of scutellum transversely striate anteriorly, moderately to heavily rugose posteriorly (Fig. 3A-F); scutellar ridge separating scutellar fovea narrow to short and wide; scutellar fovea round to subtriangular, with or without posterior rim, centre either smooth to ribbed; entire scutellar disk evenly covered in short, appressed setae (Figs 1E,3A-F).

Metapleural-propodeal complex. Metapleuron ranging from completely setose to anterior two-thirds setose, remaining posterior surface smooth, glabrous; propodeum covered in long, thin setae (Fig. 1A); cuticle deeply rugulose across entire propodeum. Nucha short, deeply striate.

Wings. Marginal cell closed along anterior margin (Fig. 1D); distinct break present in vein proximal to marginal cell (Fig. 1D); short setae present on wing surface and along margins.

Legs. Femora and tibiae orange-yellow with long, sparse setae. Tarsomeres orange-yellow, covered in short, appressed setae (Fig. 1A).

Metasoma. Ranging from black or brown to orange; petiole frequently obscured by anterior margin of tergum 3 (T3). 
A

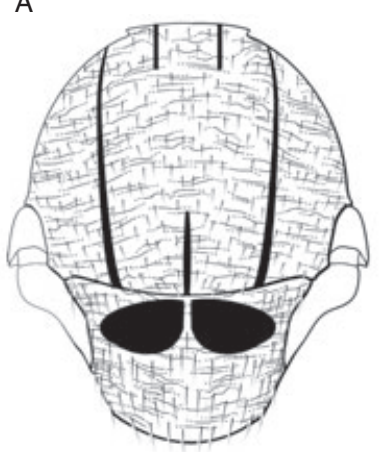

D

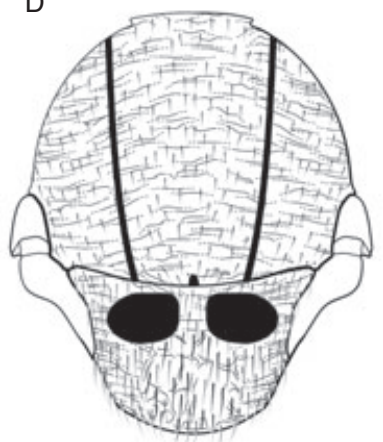

B

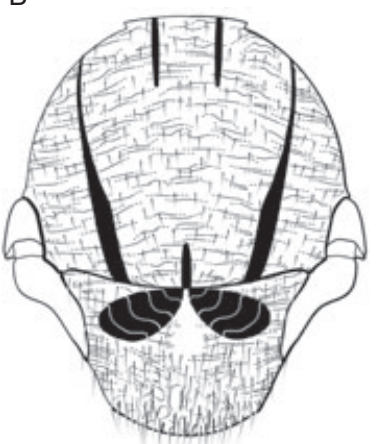

E

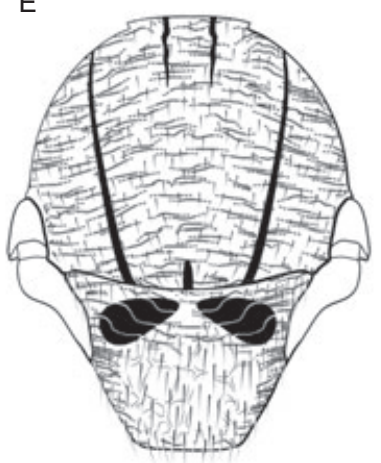

C

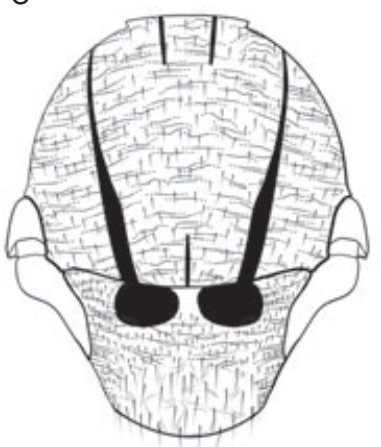

$\mathrm{F}$

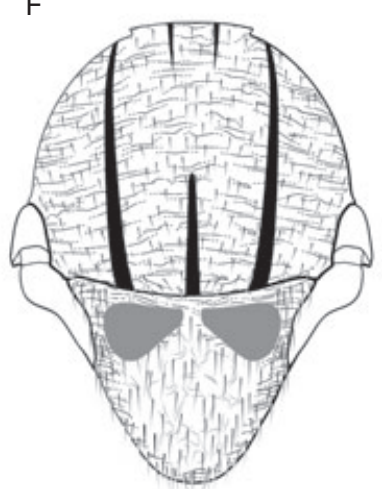

Fig. 3. Species of Mikeius and Thrasorus, dorsal view of mesosoma. (A) Mikeius berryi Buffington, n. sp.; (B) M. gatesi Buffington, n. sp.; (C) M. hartigi (Girault), n. comb.; (D) M. grandawi Buffington, n. sp.; (E) M. neumanni Buffington, n. sp.; (F) M. schauffi Buffington, n. sp.; (G) T. pillosus Weld; (H) T. schmitdae Buffington, n. sp. Drawings by M. Metz. Gray scutellar fovaeae in $(\mathrm{F})$ and $(\mathrm{H})$ indicate these impressions are shallow relative to the other species.

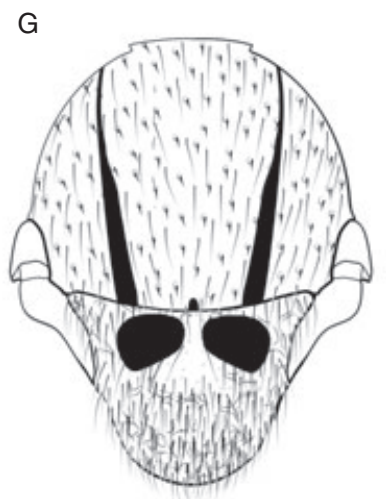

$\mathrm{H}$

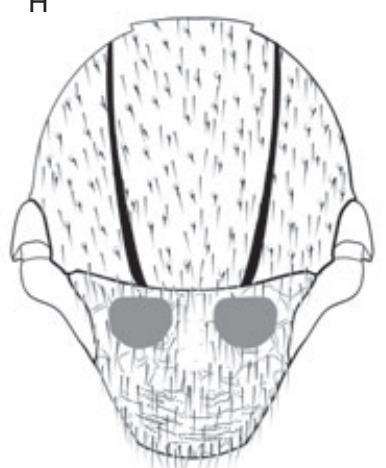

Table 2 World species of Thrasorinae. Species of Plectocynips and Pegascynips are now included in Plectocynipinae (Ros-Farré \& Pujade-Villar 2007) and not shown here

\begin{tabular}{|c|c|c|}
\hline Genus & Type species & Included species \\
\hline Mikeius Buffington & $\begin{array}{l}\text { Amblynotus hartigi } \\
\text { Girault 1930: } 2 \text { (present designation) }\end{array}$ & $\begin{array}{l}\text { Mikeius berryi Buffington } \\
\text { Mikeius gatesi Buffington } \\
\text { Mikeius grandawi Buffington } \\
\text { Mikeius hartigi (Girault) } \\
\text { Mikeius neumanni Buffington } \\
\text { Mikeius schauffi Buffington }\end{array}$ \\
\hline Myrtopsen & Myrtopsen mayri & Myrtopsen luederwaldti Dettmer (1930) \\
\hline Rübsaamen 1908: 136 & Rübsaamen (1908) (by monotypy) & $\begin{array}{l}\text { Myrtopsen mayri Rübsaamen (1908) } \\
\text { Myrtopsen mimosae Weld (1926) } \\
\text { Myrtopsen rodovalhoi Dettmer (1930) }\end{array}$ \\
\hline Scutimica & Scutimica flava & Scutimica flava \\
\hline Ros-Farré and Pujade-Villar (2007: 3) & $\begin{array}{l}\text { Ros-Farré and Pujade-Villar (2007) } \\
\text { (original designation) }\end{array}$ & $\begin{array}{l}\text { Ros-Farré and Pujade-Villar (2007) (original designation) } \\
\text { Scutimica transcarinata } \\
\text { Ros-Farré and Pujade-Villar (2007) }\end{array}$ \\
\hline Thrasorus Weld 1944: 59 & $\begin{array}{l}\text { T. pilosus } \\
\text { Weld (1944) (original designation) }\end{array}$ & $\begin{array}{l}\text { Thrasorus pilosus Weld 1944: } 59 \\
\text { Thrasorus schmitdae Buffington }\end{array}$ \\
\hline
\end{tabular}


Metasomal T4 5× length of T3; remaining terga short, telescoped within $\mathrm{T} 4$; entire metasoma shiny and smooth (Fig. 1A); setae frequently present on terga 7 and 8.

Description (male). As in female except: antenna with 14 flagellomeres, flagellomere 1 , two to three times as long as flagellomere 2, laterally excavated; apical and subapical flagellomeres distinct; metasomal T4 $3 \times$ length of T3.

Diagnosis. Differs from Thrasorus by the horizontally strigate mesoscutum; from Myrtopsen and Scutimica by the lack of syntergum; from Euceroptres by lacking an aerolet in the forewing, and having a broken hairy ring at the anterior end of metasoma; from Pegascynips by the relatively short metatibial spur.

Distribution. Australia: A.C.T., Queensland (Qld), New South Wales (NSW), Northern Territory and Western Australia. Etymology. Aside from M. hartigi, all species epithets refer to people whose first name is 'Mike', hence Mikeius, a Latinized form of Mike. The gender is masculine, ruled by second declension.

\section{Mikeius berryi sp. n. (Fig. 3A)}

Description. As in generic description with frons smooth, striate only near malar space; male antennal F1 three times longer than F2; lateral aspect of pronotum smooth; anterior of mesopleuron umbilicate; mesopleural carina present as series of weak strigae; notauli of uniform width; median mesoscutal impression present, one-third length of scutellum; scutellar fovea oval, smooth, lacking posterior rim; anterior one-fourth of metapleuron glabrous, remainder setose; metasoma orange.

Diagnosis. Differs from $M$. gatesi and $M$. hartigi by the more complete mesopleural carina and the presence of umbilicate sculpture at the anterior end of the mesopleuron; from M. neumanni and M. grandawi by the elongate median mesoscutal impression; from M. schauffi by the smooth lateral aspect of the pronotum.

Type material. HOLOTYPE. (first label) AUSTRALIA: Wanaaring, NSW, 29 October (19)49, E.F. Riek; (second label) holotype designation label. The holotype is a female, point mounted, in good condition. Deposited in ANIC. PARATYPES. AUSTRALIA: NSW. Wanaaring, 29 October (19)49, E.F. Riek (4 , $2 \sigma^{\top}$, one female missing head), one specimen labelled 'ex Eucalypt gall'; $40 \mathrm{~mL}$ W. Bourke, 28 October (19)49, NSW, E.F. Riek (1 O), second label reads 'ex Eucalypt gall'; Ryde, NSW, E. robusta (E. robusta) 28.12.29 (28 December 1929), L. Gull . . (remainder of name illegible); 'swollen stem galls \#2' (3 O'); Sydney Harbour, 6.11.30 (6 November 1930), '2030 leaf stalk gall Acacia longifolii (1 9 ); New England National Park, NSW, 19 March 1954, E.F. Riek (1 , ANIC). Qld. Bald Mountain area, 3500-4000', Via Emu Vale, 27-31.i.1972, S.R. Montieth. Victoria. 'Melb' (Melbourne), 'Univ. C.', II.96 (February 1894), bred 20.II.94 (February 20, 1894) (1 , $\left.1 \sigma^{7}\right)$.

Biology. According to specimen data labels, one series was reared by E.F. Riek from stem galls on E. robusta; a label on another specimen, collected and reared by an unknown person, reads that the specimen was reared from a stalk-leaf gall on A. longifolia. Without actual plant material, galls or host remains, the association of these specimens with these species needs confirmation.

Comments. This species appears to be rather widespread throughout Eastern and South-eastern Australia.

Etymology. Named in honour of my good friend and pilot Mike Berry.

\section{Mikeius gatesi sp. n. (Fig. 3B)}

Description. As in generic description with frons smooth dorsally, ventral one-third striate; male antennal F1 two times longer than F2; lateral aspect of pronotum smooth; anterior of mesopleuron smooth; mesopleural carina absent, occasionally with very faint strigae; notauli widened slightly posteriorly; median mesoscutal impression present, hardly impressed, short, at most one-eighth length of mesocutum; scutellar fovea subtriangular to oval, ribbed, posterior rim present; anterior one-fourth of metapleuron glabrous, remainder setose; metasoma black.

Diagnosis. Differs from M. hartigi by having a more developed scutellar fovea that is centrally ribbed and from all other species of Mikeius by the lack of a distinct mesopleural carina.

Type material. HOLOTYPE. (first label) 36.12S 148.43E, Dainers Gap, NSW, 6 February 1974, P. Morrow; (second label) ex E. pauciflora; (third label) $1585 \mathrm{~m}$. E. pauciflora, stellulata and perriniana forest; (fourth label) holotype designation. The holotype is a male, point mounted, in good condition. Deposited in ANIC. PARATYPES. AUSTRALIA. NSW. 36.12S 148.43E, Dainers Gap, NSW, 9 January 1974, P. Morrow; ex E. pauciflora; 1585 m. E. pauciflora forest. (1 q, $^{2}$ metasoma missing); 36.12S 148.43E, Dainers Gap, NSW, 21 February 1974, P. Morrow; ex E. perriniana; 1585 m. E. pauciflora, stellulata and perriniana forest ( 2 O); Rutherford Creek, Brown Mountain, NSW, 15 January 1969, J.C. Cardale \& S.R. Curtis (2 $\left.\sigma^{7}\right)$; Brown Mountain, NSW, 8 March 1963, D.H. Colless (1 $\sigma^{7}$ ); Nimmitabel, NSW, 8 March 1963, D.H. Colless (1 q). Australian Capital Territory. Canberra, 5 February 1960, E.F. Riek (1 \&). Qld. Mt. Glorious, 21 December 1961, R. Lindsay (1 \&). Northern Territory. 23.32S 133.38E, $30 \mathrm{~km} \mathrm{NW}$ by W of Alice Springs, Northern Territory, 7 October 1978, J.C. Cardale (1 $\left.\sigma^{7}\right)$.

Biology. Two labels of the type series indicate the specimens were 'ex' from either E. perriniana or E. pauciflora. As in the case of $M$. berryi, there are no host remains, plant material or galls to confirm the accuracy of this host association.

Comments. One specimen in the type series bears a label by Riek indicating that he believed this species to be $M$. hartigi (Girault). Riek, also working with the manuscript genus name 'Pelimnas', labelled several specimens as such, but this name was never published, and therefore, is not available.

Etymology. Named in honour of my friend and colleague, Mike Gates (Systematic Entomology Laboratory, USDA/ ARS). 


\section{Mikeius grandawi sp. n. (Fig. 3D)}

Description. As in generic description with frons smooth in very centre, sides and ventral one-third with horizontal strigae; lateral aspect of pronotum smooth; anterior of mesopleuron umbilicate; mesopleural carina present, distinct; notauli of uniform width; median mesoscutal impression present, short, at most one-tenth length of mesocutum; scutellar fovea round, smooth along bottom, posterior rim present; metapleuron completely setose; metasoma black. Male unknown.

Diagnosis. Differs from M. hartigi and M. gatesi by the presence of a distinct mesopleural carina; from $M$. berryi by the short median mesoscutal impression; from $M$. neumanni by the round, smooth-bottomed scutellar fovea; and from M. schauffi by the smooth lateral aspect of pronotum.

Type material. HOLOTYPE. AUSTRALIA: (first label) $37 \mathrm{mi} \mathrm{N}$ of Ajana, W(estern) A(ustralia), 16 October 1970, D.H. Colless; (second label) holotype designation label. The holotype is a female, point mounted, in good condition. Deposited in ANIC. PARATYPE. AUSTRALIA: $37 \mathrm{mi} \mathrm{N}$ of Ajana, Western Australia, 16 October 1970, D.H. Colless (1 + , ANIC).

Biology. Unknown.

Comments. This is the only recorded species from Western Australia. As with the other species of Mikeius, additional collecting likely will yield substantial range extensions.

Etymology. Named in honour of my good friend and artist Mike Grandaw.

\section{Mikeius hartigi (Girault), new combination (Figs IA-F,3C)}

\section{Amblynotus parvus Girault 1929: I-2. (not Hartig 1840)}

\section{Amblynotus hartigi Girault 1930: 2. Replacement name}

Redescription. As in generic description with frons smooth, strigate only near malar space; male antennal F2 two times longer than F3; lateral aspect of pronotum smooth; mesopleural carina absent; notauli slightly wider posteriorly; median mesoscutal impression present, one-fourth length of mesoscutum; scutellar fovea with smooth bottom, lacking posterior rim; metasoma completely black.

Diagnosis. Similar to M. gatesi in that both species lack a complete mesopleural carina (complete in all other species); differs from M. gatesi having most of the frons smooth (lower one-third of frons in M. gatesi horizontally strigate), bottom of scutellar fovea smooth, not rimmed posteriorly (ribbed and slightly rimmed posteriorly in $M$. gatesi); differs from all other species of Mikeius by the lack of a mesopleural carina.

Type material. HOLOTYPE. AUSTRALIA. (first label) Bright, Victoria, F.E. Wilson, September 1928; (second label) bred from Eucalyptus gall; (third label) holotype label (pink); (fourth label) Pelimnas hartigi (Gir) E.F. Riek, det 1953 (in Riek's hand); (fifth label) A. parvus Girault, female, type (in
Table 3 Hymenoptera associated with Ophelimus galls on Eucalyptus cineraria (J. La Salle \& I.-K. Kim, pers. comm.)

\begin{tabular}{lll}
\hline Species & Family & Subfamily/Tribe \\
\hline Ophelimus sp.1 (gall inducer) & Eulophidae & Ophelimini \\
Ophelimus sp.2 & Eulophidae & Ophelimini \\
Tetrastichinae sp.1 & Eulophidae & Tetrastichinae \\
Tetrastichinae sp.2 & Eulophidae & Tetrastichinae \\
Pirenini sp.1 & Pteromalidae & Pireninae \\
Ditropinotella sp. & Pteromalidae & Ditropinotellinae \\
Megastigmus sp. & Torymidae & Megastigminae \\
Bootanellus sp. & Torymidae & Megastigminae \\
Eurytoma sp. & Eurytomidae & Eurytominae \\
Mikeius hartigi & Figitidae & Thrasorinae \\
\hline
\end{tabular}

Girault's hand). The holotype is a female (based on the original description), in poor condition, missing the antennae, metasoma and most legs. Deposited in QM (Qld Museum, Brisbane, Australia).

Additional material. NON-TYPES. AUSTRALIA. Australian Capital Territory. Canberra, CSIRO Black Mountain Laboratories outside herbarium, coll 19.IX. 2002J. La Salle, N. Fisher. (13 O', 10 q, ANIC; 12 \&, $13 \sigma^{7}$, NMNH: National Museum of Natural History, Washington, DC, USA).

Image depository. Collection of images of this species located at http://morphbank.net/Show/?id=110362.

Biology. M. hartigi emerged from Ophelimus sp. galls on E. cinerea from the middle of October to the middle of November (Fig. 1F). The species is biparental, producing almost equal numbers of females and males (J. La Salle \& I.-K. Kim, pers. comm.). A total of 10 other species of Hymenoptera emerged from the galls on E. cinerea (Table 3). The biology of all these species has not been resolved, and species could be parasitoids, inquilines or even gall formers within or adjacent to the galls induced by the Ophelimus sp.

\section{Mikeius neumanni sp. n. (Fig. 3E)}

Description. As in genus description with frons densely setose in very centre, sides and ventral one-third with horizontal strigae; lateral aspect of pronotum moderately crenulate with long setae; anterior of mesopleuron striate; mesopleural carina present, distinct; notauli of uniform width; median mesoscutal impression present, short, notch-like; scutellar fovea subtriangular, ribbed along bottom, posterior rim present; metapleuron completely covered by long setae; metasoma black.

Diagnosis. Differs from M. hartigi and M. gatesi by the presence of a distinct mesopleural carina (reduced in males); from $M$. berryi and M. schauffi by the short median mesoscutal impression; and from M. grandawi by the triangular, ribbed scutellar fovea.

Material examined. HOLOTYPE. AUSTRALIA (first label) Mt. Nebo, S.E. Qld, 24.xi.1970, S.R. Monteith; (second label) holotype designation. The holotype is a female, point mounted, in good condition. Deposited in ANIC.

Additional material. None.

Biology. Unknown

Journal compilation @ 2008 Australian Entomological Society No claim to original US government works 
Etymology. Named in honour of my good friend Mike Neumann.

\section{Mikeius schauffi sp. n. (Fig. 3F)}

Description. As in generic description with frons densely setose in very centre, sides with horizontal strigae; lateral aspect of pronotum with moderate striae along ventral onethird; anterior of mesopleuron umbilicate; mesopleural carina present, distinct; notauli of uniform width; median mesoscutal impression present, moderately long, reaching to near middle of mesoscutum; scutellar fovea oblong, smooth along bottom, posterior rim weakly present; metapleuron completely covered by medium length setae; metasoma orange.

Diagnosis. Differs from $M$. hartigi and $M$. gatesi by the presence of a distinct mesopleural carina; from M. neumanni and $M$. grandawi by the relatively long mesoscutal impression; and from $M$. berryi by oblong, weakly bordered scutellar fovea.

Type material. HOLOTYPE. AUSTRALIA: (first label) 23.36S 133.35E, $32 \mathrm{~km}$ West-Northwest of Alice Springs, N(orthern T(erritory), 8 October 1978, J.C. Cardale; (second label) ex alcohol collection; (third label) holotype designation label. The holotype is a female, point mounted, in good condition. Deposited in ANIC.

Additional material. None.

Biology. Unknown

Etymology. Named in honour of Mike Schauff, Plant Sciences Institute, USDA.

\section{Thrasorus Weld (Figs 2A-E,3G-H)}

\section{Thrasorus pilosus Weld I944: 59. Type species by original designation}

Redescription (female). Head. Polished on frons, malar space and gena; setose around toruli, ocelli, and occiput (Fig. 2B,C). Antennae orange, scape $1.5 \times$ length of radicle, short appressed setae on all flagellomeres, 12 flagellomeres present, moniliform.

Mesosoma. Lateral surface of pronotum polished; sparsely covered in moderately long setae (Fig. 2B). Mesopleuron polished; mesopleural carina present; mesopleural triangle deeply impressed, setose, clearly defined along all edges (Fig. 2B). Mesoscutum lightly pitted with small punctures and moderately setose; cuticle between punctures shiny; notauli complete, originating at anterior end of parascutal impression; (Figs 2C,3G-H). Disk of scutellum moderately rugose posteriorly, smooth anteriorly; scutellar ridge separating scutellar fovea short; entire disk sparsely covered in long, thin setae (Figs 2C,3G-H).

Metapleural-propodeal complex. Entire metapleuron and propodeum covered in long, thin setae such that surface sculpture is entirely obscured (Fig. 2B); cuticle deeply rugulose across entire propodeum. Nucha short, deeply striate.

Metasoma. Petiole obscured by anterior margin of T3. Metasomal T4 $4 \times$ length of T3; remaining terga short, tele- scoped within T4; entire metasoma shiny and smooth (Fig. 2A). Setal band at base of metasoma incomplete dorsally.

Wings. Marginal cell closed along anterior margin (Fig. 2D); short setae present on wing surface and along margins.

Legs. Femora, tibiae orange; long, sparse setae present. Tarsomeres orange, covered in short, appressed setae (Fig. 2A). Redescription (male). As in female with first flagellomere of antennae slightly longer, laterally excavated; length of metasoma slightly smaller than female.

Diagnosis. Differs from Mikeius by the smooth mesoscutum; from Myrtopsen and Scutimica by the lack of a syntergum; from Euceroptres by lacking an aerolet in the forewing and having a broken hairy ring at anterior end of metasoma; and from Pegascynips by lack of relatively long metatibial spur.

Distribution. Australia: NSW, Tasmania, A.C.T. and Victoria.

\section{Thrasorus pilosus Weld (Figs 2A-E,3G)}

Redescription. As in generic description with head and metasoma orange, mesosoma black; notauli noticeably wider posteriorly; mesoscutal impression reduced to a distinct notch in posterior margin of mesoscutum; anterior margin of mesopleuron heavily to moderately setose.

Diagnosis. Differs from T. schmidtae Buffington n. sp. by the presence of setae along anterior margin of mesopleuron and a distinct notch-like remnant of the mesoscutal impression.

Type material. HOLOTYPE. AUSTRALIA: (first label) NSW; (second label) Sydney, November 1915; (third label) J.C. Bridwell, collector; (fourth label, red) Type no. 56813 USNM (NMNH); (fifth label, in Weld's hand) T. pilosus Weld (1944). The holotype is a point mounted female, in moderate condition, deposited in NMNH. PARATYPES. AUSTRALIA: NSW. Sydney, November 1915, J.C. Bridwell collector (3 $\sigma^{\top}$, $\mathrm{NMNH}$ ). All paratypes have their metasomata disarticulated from the rest of the body.

Additional material. NSW. Yallingup, November 1913, R.E. Turner 1914-190 (1 ○', NMNH); Coonabarabran, 24 November 1936, Carter, 2473, small oval gall on E. robusta (1 $q$, ANIC); Sydney, Sydney Harbor, W. WF., 29 October 1930, 2136, large round gall, E. robusta (1 + , ANIC); Sydney, Sydney Harbor, W. WF., 19 November 1930, 2036, round stem, E. robusta (1 \&, ANIC); 40 mi W. Burke, 28 October 1949, E.F. Riek, on eucalypt gall (1 ○', ANIC); Nimmitabel, 8 March 1963, D.H. Colless (1 ○', ANIC); 36.12S 148.4E, Dainers Gap, NSW, 21 February 1974, P. Morrow, ex E. perriniana, $1585 \mathrm{~m}$. E. pauciflora, stellulata and perriniana forest (1 \&, $1 \sigma^{7}$, ANIC); Brown Mtn., NSW, 15 January 1969, J.C. Cardale \& S.R. Curtis (1 $\sigma^{7}$, ANIC). Australian Capital Territory. Canberra, 27 December 1960, E.F. Riek (1 O , ANIC). Victoria. Melbourne University, 10-12-94 (12 October 1894?) (4 , 2 ㅇ, ANIC); Melbourne, on Eucalyptus, 11-94 (November 1894?) (2 ơ, 1 ㅇ, ANIC); Tambo Crossing, January 1936, F.E. Wilson, bred from sticks of A. dealbata (1 $\sigma^{\top}$, ANIC). Tasmania. Bicheno, Tasm., 1-19 December 1981, H.J. Elliott, E. sieberi stem galls, ex ethanol (4 O', ANIC). 
Biology. According to label data, several specimens were reared from $E$. robusta and $E$. sieberi. Other specimens were simply associated with Eucalyptus (on or 'ex') and A. dealbata. As with other species discussed in this paper, no host remains are associated with any of these records.

Image depository. A collection of images of this species is located at http://morphbank.net/Show/?id=110363.

\section{Thrasorus schmidtae sp. n. (Fig. 3H)}

Description. As in generic description with head, mesosoma, metasoma dark brown; notauli entirely of equal width; mesoscutal impression completely absent; anterior margin of mesopleuron glabrous.

Diagnosis. Differs from T. pilosus by the glabrous anterior margin of the mesopleuron and by the total lack of a mesoscutal impression.

Type material. HOLOTYPE. AUSTRALIA. (first label) Woombye, near Nambour, Qld, 11-16 October 1965, D.H. Colless; (second label) holotype designation label. The type is a female, point mounted, in good condition. Deposited in ANIC.

Additional material. None.

Biology. Unknown.

Etymology. Named in honour of Hazel Schmidt (Plant Sciences Institute, USDA) who played a critical role in obtaining the imaging equipment used to illustrate the species in this paper for the Systematic Entomology Laboratory.

\section{DISCUSSION}

Weld (1944, 1952) placed T. pilosus Weld within the entomophagous figitid subfamily Figitinae. The species remained in Figitinae until Riek (1970) transferred it to the inquiline Cynipidae (referred to as Cynipinae and not Synergini sensu Ronquist (1999)). Riek (1970) suggested that, based on the association of T. pilosus with galls, as well as features of the mesoscutum and hypopygium, the taxon was not a figitid. The first published host record for Thrasorus was that of Riek (1971), which listed the host as a Melanosomellini (Brachyscelidiphagini) (Pteromalidae) chalcidoid, but offered no references or data on the source of this record.

Upon further examination of specimens housed in ANIC, it is clear that the specimens used in the present study were the very same as those used by Riek (1971). Unfortunately, as stated earlier in this work, there are no host remains (plant material or galls) that allow for any confirmation of the label data. Specifically, the reference to Melanosomellini as the host on Acacia, is based on a series of both figitids and pteromalids, all mounted together on large cards, with 'host' data recorded on the reverse side as 'Acacia gall'; the handwriting is far from legible, and the only other information I was able to obtain from these labels was 'Qld'. One of the two large cards may have, at one point, contained some form of host remains, likely a gall, judging from a large glue spot on the larger of the two cards. Riek had placed a determination label on one of the two large card samples, stating that taxon was 'T. berlesei (Grlt)'; my investigations indicate that this name was never published by Girault (or Riek), although there is a specimen in the QM labelled as 'A. berlesei Girault'. This specimen also bears a holotype label, and aside from the label by Girault (in Girault's hand), the specimen bears no other information, not even locality data. It is not clear why Girault never published this name, but it is possible that he was awaiting more specimens with complete data. This specimen should not be considered a holotype, and the name 'A. berlesei' is considered unavailable because the name has never been published.

Based on the gall-associated biology, Riek (1970) transferred this taxon to Cynipidae. Conversely, Kovalev (1994) used these same data to remove Thrasorus from Cynipidae and erect Thrasoridae, a new family group name that also included Riekcynips australis (Kovalev 1994). Kovalev (1994) further suggested that thrasorids were among the most basal of microcynipoids, hinting that they were closely related to the gallinducing Cynipidae.

Ronquist (1999) considered Riekcynips a nomen nudum because no type specimen was designated for this species. Although no type specimen was designated, a type species was selected and, according to the code under which the genus was originally described (ICZN 1985, Art. 73.1.4), no type specimen was required. Despite that the name is available, this genus cannot be placed confidently within Thrasorinae. Therefore, I follow Ros-Farré and Pujade-Villar (2007) and consider Riekcynips australis Kovalev incertae sedis (Table 4).

Ronquist (1999) reclassified Thrasorus within the Thrasorinae, a subfamily of Figitidae, and included five genera formerly referred to as the figitoid inquilines (Ronquist 1994, 1995); these taxa are Euceroptres, Myrtopsen, Pegascynips, Plectocynips and Thrasorus. Ronquist (1999) supported this move by citing that these genera all possessed the two synapomorphies of figitids, i.e. base of ovipositor with a distinct point of weakness (viz. Fig. 6A,B, Ronquist 1995) and the $\mathrm{R}_{\mathrm{s}}+\mathrm{M}$ forewing vein issuing from a point close to $\mathrm{Cu}$, at the posterior end of the basal vein (viz. Fig. 11, Ronquist 1995). Ronquist (1999) further characterised members of the Thrasorinae as all possessing a 'distinctly swollen metacoxa'. The phylogenetic utility of this last character has yet to be critically evaluated (F. Ronquist, pers. comm.; M.L. Buffington, pers. obs.). It should be noted that Kovalev (1994) recognised the discrepancy in the forewing venation of thrasorids and cynipids, which appears to be the chief reason for their removal from Cynipidae (along with biological data). More recently, Buffington and Liljeblad (2008) erected Euceroptrinae to accommodate Euceroptres since this genus renders Thrasorinae paraphyletic (Buffington et al. 2007).

Table 4 Species incertae sedis previously classified as Thrasorinae

\begin{tabular}{lcc}
\hline Genus & Type species & Included species \\
\hline Riekcynips & Riekcynips australis & Riekcynips \\
Kovalev (1994) & $\begin{array}{l}\text { Kovalev (1994) } \\
\text { (original designation) }\end{array}$ & australis Kovalev \\
& \\
\hline
\end{tabular}




\section{ACKNOWLEDGEMENTS}

Funding for the field component of this research provided by the Hymenoptera Assembling the Tree of Life NSF EF-0337220 (awarded in part to Fredrik Ronquist). John La Salle (ANIC) and Il-Kwon Kim (ANIC) provided critical data concerning the biology of $M$. hartigi, a long series of reared specimens for my examination, and identifications of Chalcidoidea reared from Ophelimus galls. J. La Salle originally brought the Ophelimus system to my attention and assisted with loans of both primary type material and other specimens, as well as assisted me with earlier drafts of this paper. Chris Burwell (QM) assisted with the loan of Girualt specimens. Marie Metz (Systematic Entomology Laboratory, Washington, DC) provided the illustrations for Figure 3, as well as teaching me many Photoshop tips; Shelah Morita (NCSU) assisted with the development of the concept of the name Mikeius. Scientists Jens Prena, Thomas Henry (Systematic Entomology Laboratory, Washington, DC), John La Salle (ANIC, Canberra) and Ken Walker (Museum Victoria, Melbourne) provided critical reviews of this paper.

\section{REFERENCES}

Buffington ML \& Liljeblad J. 2008. The description of Euceroptrinae, a new subfamily of Figitidae (Hymenoptera), including a revision of Euceroptres Ashmead, 1896, and the description of a new species. Journal of Hymenoptera Research 17, 44-56.

Buffington ML, Burks R \& McNeil L. 2005. Advanced techniques for imaging microhymenoptera. American Entomologist 51, 50-54.

Buffington ML, Nylander JAA \& Heraty J. 2007. The phylogeny and evolution of Figitidae (Hymenoptera: Cynipoidea). Cladistics 23, $1-29$.

Castro L \& Dowton M. 2006. Molecular analyses of the Apocrita (Insecta: Hymenoptera) suggest that the Chalcidoidea are sister to the diaprioid complex. Invertebrate Systematics 20, 603-614.

Dettmer HSJ. 1930. Beschreibung von funf neuen Cynipidenarten worunter eine neue Gattung. Broteria (Ser. Zool.) 26, 54-68.

Dowton M \& Austin A. 2001. Simultaneous analysis of 16S, 28S, COI and morphology in the Hymenoptera: Apocrita - evolutionary transitions among parasitic wasps. Biological Journal of the Linnean Society 74, 87-111.

Fontal-Cazalla FM, Buffington M, Nordlander G et al. 2002. Phylogeny of the Eucoilinae (Hymenoptera: Cynipoidea: Figitidae). Cladistics 18, 154-199.

Girault AA. 1929. New Pests from Australia VI, 4 pages. Brisbane, 30 September 1929.
Girault AA. 1930. New Pests from Australia VII, 3 pages. Brisbane, 10 February 1930.

Harris R. 1979. A glossary of surface sculpturing. State of California, Department of Food and Agriculture, Occasional Papers in Entomology 28, 1-31.

Hartig T. 1840. Über die Familie der Gallwespen. Zeitschrift für die Entomologie, herausgegeben von Ernst Friedrich Germar 2, 176-209.

ICZN. 1985. International Code of Zoological Nomenclature, 3rd edn. ICZN, London, UK.

Kovalev OV. 1994. Paleontological history, phylogeny and the system of brachycleistogastromorphs and cynipomorphs (Hymenoptera, Brachycleistogastromorpha infraorder n., Cynipomorpha infraorder n.) with description of new fossil and recent families, subfamilies and genera. Entomologicheskoe Obozrenie 73, 385-426 [Translated to English in Entomological Review 74, 105-147].

Nordlander G. 1984. [What do we know about parasitic cynipoids (Hymenoptera)?]. Entomologisk Tidskrift 105, 36-40. [in Swedish].

Riek EF. 1970. Superfamily Cynipoidea. In: The Insects of Australia (ed. I MacKerras), pp. 910-913. CSIRO, Melbourne University Press, Melbourne, Australia.

Riek EF. 1971. A new family of cynipoid wasps (Hymenoptera: Cynipoidea) from Australia. In: Entomological Essays to Commemorate the Retirement of Professor K. Yasumatsu (eds S Asahinas, J Linsley Gressitt, Z Hidaka, T Nishida, K Nomura), pp. 107-112. Holuryukan Publishers Co. Ltd., Tokyo, Japan.

Ronquist F. 1994. Evolution of parasitism among closely related species: phylogenetic relationships and the origin of inquilinism in gall wasps (Hymenoptera, Cynipidae). Evolution 48, 241-266.

Ronquist F. 1995. Phylogeny and early evolution of the Cynipoidea (Hymenoptera). Systematic Entomology 20, 309-335.

Ronquist F. 1999. Phylogeny, classification and evolution of the Cynipoidea. Zoologica Scripta 28, 139-164.

Ronquist F \& Nordlander G. 1989. Skeletal morphology of an archaic cynipoid (Hymenoptera: Ibaliidae). Entomologica Scandinavica Supplements 33, 1-40.

Ronquist F, Rasnitsyn AP, Roy A, Eriksson K \& Lindgren M. 1999. Phylogeny of the Hymenoptera: a cladistic reanalysis of Rasnitsyn's (1988) data. Zoologica Scripta 28, 13-50.

Ros-Farré P \& Pujade-Villar J. 2007. Plectocynipinae, a new subfamily of Figitidae and description of a new Neotropical genus of Thrasorinae (Hymenoptera: Cynipoidea). Zootaxa 1583, 1-13.

Rübsaamen EH. 1908. Beiträge zur Kenntnis aussereuropäischer Zooceciden. III. Beitrag. Gallen aus Brasilien und Peru. Marcellia 6, $110-173$.

Weld L. 1926. Field notes on gall-inhabiting cynipid wasps with descriptions of new species. Proceedings of the United States National Museum 68, 1-131.

Weld L. 1944. Description of new Cynipidae including two new genera (Hymenoptera). Proceedings of the Entomological Society of Washington 46, 55-66.

Weld L. 1952. Cynipoidea (Hym.) 1905-50. Privately Printed, Ann Arbor, Michigan.

Accepted for publication 23 December 2007. 